\title{
Dependence on Myb expression is attenuated in myeloid leukaemia with $\mathrm{N}$-terminal CEBPA mutations
}

\author{
Giacomo Volpe ${ }^{1,2}$ (D), Pierre Cauchy ${ }^{3}$, David S Walton ${ }^{1}$, Carl Ward ${ }^{1,2}$ (D), Daniel Blakemore ${ }^{1}$, Rachael Bayley ${ }^{1}$, Mary L Clarke ,

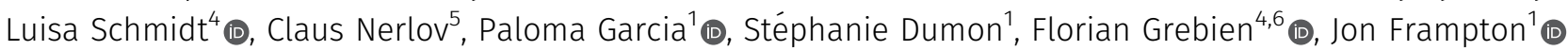

\begin{abstract}
Mutations at the $\mathrm{N}$ - or C-terminus of C/EBP $\alpha$ are frequent in acute myeloid leukaemia (AML) with normal karyotype. Here, we investigate the role of the transcription factor Myb in AMLs driven by different combinations of CEBPA mutations. Using knockdown of Myb in murine cell lines modelling the spectrum of CEBPA mutations, we show that the effect of reduced Myb depends on the mutational status of the two Cebpa alleles. Importantly, Myb knockdown fails to override the block in myeloid differentiation in cells with biallelic $\mathrm{N}$-terminal C/EBP $\alpha$ mutations, demonstrating for the first time that the dependency on Myb is much lower in AML with this mutational profile. By comparing gene expression following Myb knockdown and chromatin immunoprecipitation sequencing data for the binding of C/EBP $\alpha$ isoforms, we provide evidence for a functional cooperation between C/EBP $\alpha$ and Myb in the maintenance of AML. This co-dependency breaks down when both alleles of CEBPA harbour $\mathrm{N}$-terminal mutations, as a subset of $\mathrm{C} / \mathrm{EBP} \alpha$-regulated genes only bind the short p30 C/EBP $\alpha$ isoform and, unlike other $\mathrm{C} / \mathrm{EBP} \alpha$-regulated genes, do so without a requirement for Myb.
\end{abstract}

DOI 10.26508/lsa.201800207 | Received 7 October 2018 | Revised 7 March 2019 | Accepted 7 March 2019 | Published online 15 March 2019

\section{Introduction}

Acute myeloid leukaemia (AML), one of the most common and deadliest forms of proliferative neoplasms, is established through a stepwise acquisition of genetic and epigenetic alterations that result in the malignant transformation of haematopoietic progenitor cells (Kelly \& Gilliland, 2002; Moore, 2005). Often, AML arises through the collaboration between mutations affecting transcription factors (e.g., CEBPA, PU.1, and RUNX1) and signalling proteins (such as FLT3, RAS, and KIT) that lead to an aberrant proliferation capacity coupled with a disruption of terminal myeloid differentiation (Tenen, 2003; Rosenbauer \& Tenen, 2007).
$\mathrm{C} / \mathrm{EBP} \alpha$, a leucine zipper transcription factor with a known tumour suppressor function, has been demonstrated to play an important role in granulocytic development and in the maintenance of haematopoietic stem cell homeostasis (Porse et al, 2001, 2005; Zhang et al, 2004; Koschmieder et al, 2009; Welner et al, 2013; Ye et al, 2013). C/EBPa is translated as two major isoforms, namely a full-length 42-kD form ( $p 42$ ) and a truncated 30-kD protein ( $\mathrm{p30}$ ) that arises from a downstream translational initiation codon (Lin et al, 1993). Mutations in the CEBPA gene are frequently associated with leukaemia, being found in $8-14 \%$ of all de novo AML with normal karyotype (Nerlov, 2004; Leroy et al, 2005; Song et al, 2015) and typically involve both alleles. C/EBP $\alpha$-mutant proteins are classified into two major groups: (i) C-terminal insertions or deletions within the basic region leucine zipper DNA-binding domain; and (ii) N-terminal mutations that lead to the complete ablation of p42 while retaining normal p30 function (Pabst et al, 2001; Leroy et al, 2005; Fasan et al, 2014). Most patients carrying CEBPA mutations harbour one allele with an $\mathrm{N}$-terminal mutation and one with a C-terminal mutation, with homozygosity for $\mathrm{N}$ - or C-terminal mutations being less common (Gombart et al, 2002; Pabst \& Mueller, 2007). Furthermore, several reports have demonstrated that biallelic mutations of CEBPA are associated with a favourable outcome, when not found in association with FLT3-activating mutations (Renneville et al, 2009; Dufour et al, 2010).

Efforts aimed at understanding how mutations or oncoproteins may cooperate in driving the leukaemogenesis have pointed to cooperation between $\mathrm{C} / \mathrm{EBP} \alpha$ and other transcription factors, such as RUNX1, MYB, and PU.1. We have previously demonstrated the functional cooperation of Myb and C/EBPa in the regulation of the Flt3 gene in both haematopoietic and leukaemia stem cells (Volpe et al, 2013, 2015). Our studies indicated that Myb and C/EBP $\alpha$ act cooperatively through their combined activity on promoter and intronic elements in the Flt3 gene (Volpe et al, 2013). Furthermore, we reported a strong linear correlation between expression of the

\footnotetext{
${ }^{1}$ Institute of Cancer and Genomic Sciences, College of Medical and Dental Sciences, University of Birmingham, Birmingham, UK ${ }^{2}$ Key Laboratory of Regenerative Biology, Joint School of Life Sciences, Guangzhou Institutes of Biomedicine and Health, Chinese Academy of Sciences, Guangzhou, and Guangzhou Medical University, Guangzhou, China ${ }^{3}$ Max Planck Institute of Immunobiology and Epigenetics, Freiburg, Germany ${ }^{4}$ Ludwig Boltzmann Institute for Cancer Research, Vienna, Austria ${ }^{5}$ Medical Research Council Molecular Haematology Unit, Weatherall Institute of Molecular Medicine, University of Oxford, Oxford, UK ${ }^{6}$ Institute of Medical Biochemistry, University of Veterinary Medicine, Vienna, Austria
}

Correspondence: j.frampton@bham.ac.uk; g.volpe@bham.ac.uk

Giacomo Volpe and Pierre Cauchy are joint first authors

Stéphanie Dumon, Florian Grebien, and Jon Frampton are joint senior authors 
two transcription factors and FLT3 RNA levels in human CN-AML, adding to an increasing body of evidence that points to MYB being a crucial component of leukaemia maintenance and oncogene addiction (Hess et al, 2006; Zuber et al, 2011; Clarke et al, 2017).

Our findings on the cooperation of Myb and C/EBP $\alpha$ in Flt3 gene regulation prompted us to investigate the global extent of this cooperation in leukaemia and to determine how manipulation of Myb expression might impact on the maintenance of C/EBP $\alpha$-driven leukaemia. To address this, we performed genetic manipulation studies in murine haematopoietic progenitor cell lines harbouring either wildtype C/EBP $\alpha$ or the most frequently occurring combinations of biallelic CEBPA mutations, that is $\mathrm{N}^{\text {ter }} / \mathrm{N}^{\text {ter }}$ or $\mathrm{N}^{\text {ter }} / \mathrm{C}^{\text {ter }}$ to determine the biological and molecular consequences of reduced Myb activity on the leukaemia driven by those mutations. Here, we show that reducing Myb activity can override the differentiation barrier, although the dependency on Myb expression generally observed in leukaemia is minimal in the presence of CEBPA biallelic N-terminal mutations.

\section{Materials and Methods}

\section{Cell lines}

Cells were cultured in RPMI medium supplemented with $10 \%$ fetal bovine serum, $50 \mathrm{U} / \mathrm{ml}$ penicillin, $50 \mu \mathrm{g} / \mathrm{ml}$ streptomycin, and $2 \mathrm{mM}$ L-glutamine. The culture of FMH9 cells (Volpe et al, 2013) were supplemented with $50 \mathrm{ng} / \mathrm{ml}$ stem cell factor, $5 \mathrm{ng} / \mathrm{ml} \mathrm{GM-CSF}$, $5 \mathrm{ng} / \mathrm{ml} \mathrm{IL-3} \mathrm{(IL3),} \mathrm{and} 5 \mathrm{ng}$ IL-6 (IL6), whereas KL cells (GV, JF, and FG, unpublished) and LL cells (Grebien et al, 2015; Schmidt et al, 2019) required $2 \mathrm{ng} / \mathrm{ml}$ IL3. Both $\mathrm{KL}$ and LL have been established by serial replating of E14.5 foetal liver cells obtained from mice homozygous for the Lp30 allele (Kirstetter et al, 2008) or carrying both Lp30 and K313KK alleles (Bereshchenko et al, 2009). Briefly, the KL and LL cell lines were obtained by performing six rounds of replating in M3434 semisolid medium (Stem Cell Technologies Inc) followed by an initial liquid culture for $4 \mathrm{wk}$ in the presence of stem cell factor (50 $\mathrm{ng} / \mathrm{ml})$, IL3 $(2 \mathrm{ng} / \mathrm{ml})$, and IL6 $(2 \mathrm{ng} / \mathrm{ml})$. After this initial period, the cells were transferred into the culture medium described above. All cytokines were purchased from Peprotech EC.

\section{Transfection experiments, cell viability, proliferation, apoptosis, and differentiation assays}

In total, $5 \times 10^{6} \mathrm{FMH9}, \mathrm{KL}$, or LL cells were electroporated with 300 mM of Myb siRNA (s70212, Ambion; Life Technologies) or a scrambled negative control siRNA (4390843 Silencer Select Negative Control \#1; Life Technologies) using an Amaxa 4D-nucleofector with solution SF Cell Line (V4XC-2024; Lonza) and program EO-100 for FMH9 cells or solution P3 Primary Cells (V4XP-3024; Lonza) and program DS-120 for KL and LL cells.

After transfection, the cells were plated at a density of $10^{6}$ cells $/ \mathrm{ml}$ and viable cells counted and passaged at a ratio of 1:2 every $24 \mathrm{~h}$ for 4 consecutive days. Cell cycle analysis was performed by labelling transfected cells (48 h post-nucleofection) with $10 \mu \mathrm{M}$ BrdU for $1 \mathrm{~h}$. Cells were co-stained with 7-AAD (A9400-1mg; Sigma-Aldrich) and BrdU using the BrdU flow kit (8811-6600; BD Bioscience) according to the manufacturer's instructions, as previously described (Bayley et al,
2018). Apoptosis analysis was performed using the Annexin $V$ kit (eBioscience) as previously described (Volpe et al, 2015). The percentage of apoptotic cells was obtained by performing live cells gating. Proliferation analysis was performed using CellTrace carboxyfluorescein succinimidyl ester (CFSE) Cell Proliferation Kit (C34554; Thermofisher Scientific). Assessment of differentiation following Myb knockdown was achieved by flow cytometry/ immunofluorescence staining of the cells with anti-CD11b PE-Cy7 (25-0112-81; eBioscience) anti-Gr-1 APC (14-5921-82; eBioscience), anti-CD135 PE (12-1351-81; eBioscience), and anti-CD117 PE-Cy5 (151171-82; eBioscience). Acquisition and analysis of flow cytometric data were performed using Cyan ADP with either Summit 4.4 software (Beckman Coulter) or FlowJo software (FlowJo, LLC).

\section{Quantitative reverse transcriptase polymerase chain reaction (RT-PCR) analysis}

$10^{6}$ cells from each line were harvested $24 \mathrm{~h}$ post-transfection. RNA was extracted using RNeasy Mini kit (QIAGEN), and first-strand CDNA synthesis was performed using standard protocols. Quantitative PCR reactions were performed using predesigned Taqman gene expression assays as previously described (Volpe et al, 2015).

\section{Statistical analysis}

Statistical significance was determined by performing $t$ test for pairwise comparison, and the $P$-values are indicated where appropriate. Analysis of MYB expression in human patient array data presented in Fig 1A was performed using non-parametric Kruskal-Wallis test. All statistical analyses were performed using GraphPad Prism 7 (GraphPad Software Inc).

\section{Bioinformatic analyses}

Details of the methodologies used to analyse and compare RNAseq, microarray, and ChIP-seq data, including Gene Ontology (GO) and Gene Set Enrichment Analysis (GSEA) comparisons, can be found in the Supplementary Information.

\section{RNA-sequencing}

For RNA-Seq, libraries were prepared using the Illumina TruSeq Stranded kit according to the manufacturer's instructions. Sequencing was performed at the Institute of Medical Biochemistry, University of Veterinary Medicine, Vienna, Austria, and in Genomics Birmingham, University of Birmingham, Birmingham, UK, on Illumina HiSeq 2500 and NextSeq 500 sequencers, respectively.

\section{Data availability}

RNA-Seq data generated in this study are available at the Gene Expression Omnibus under series GSE119348.

\section{Results}

High MYB expression is associated with CEBPA mutations in AML

Previous studies have provided evidence for functional cooperation between C/EBP $\alpha$ and MYB in activating the expression of key genes 

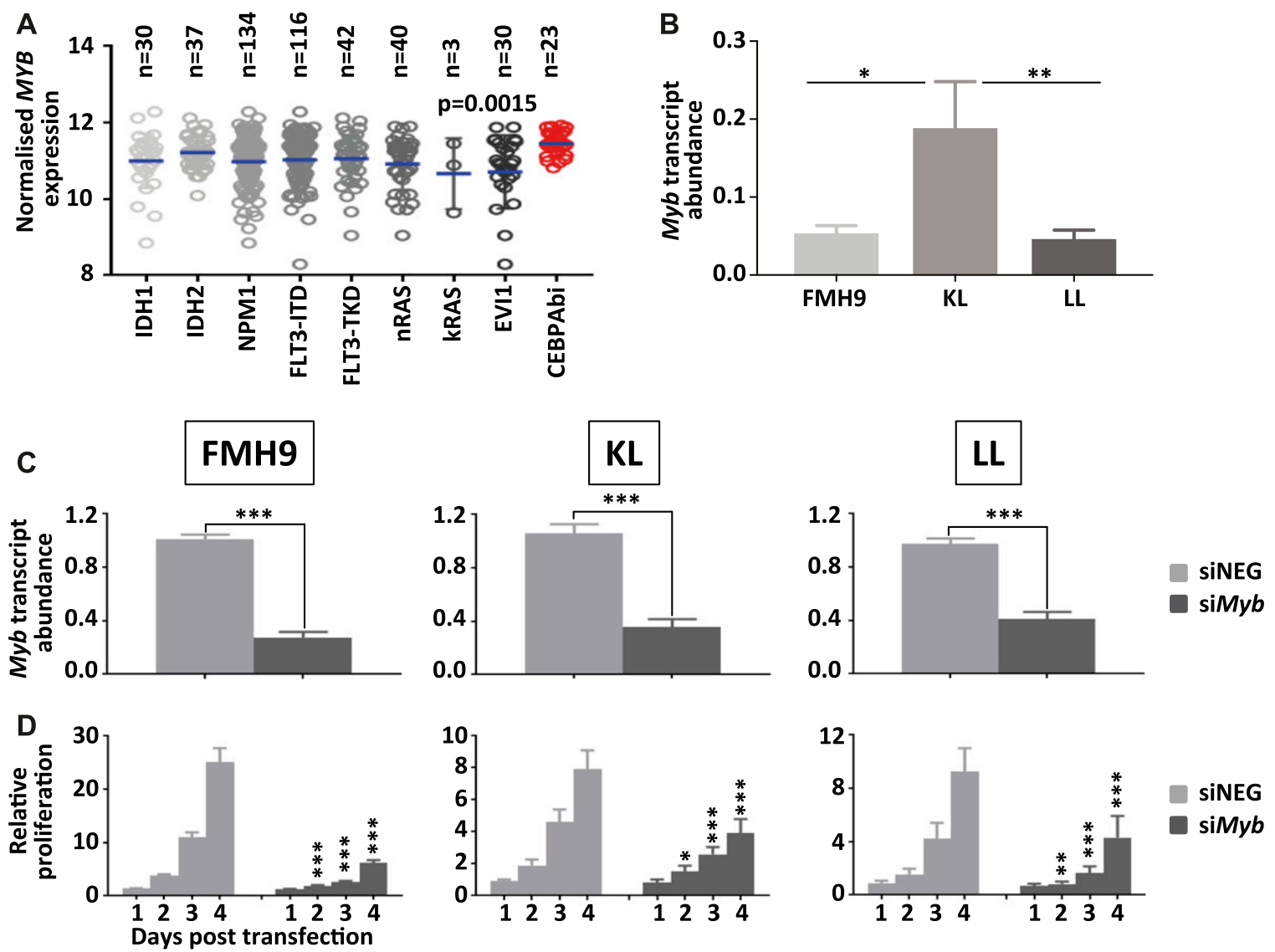

E
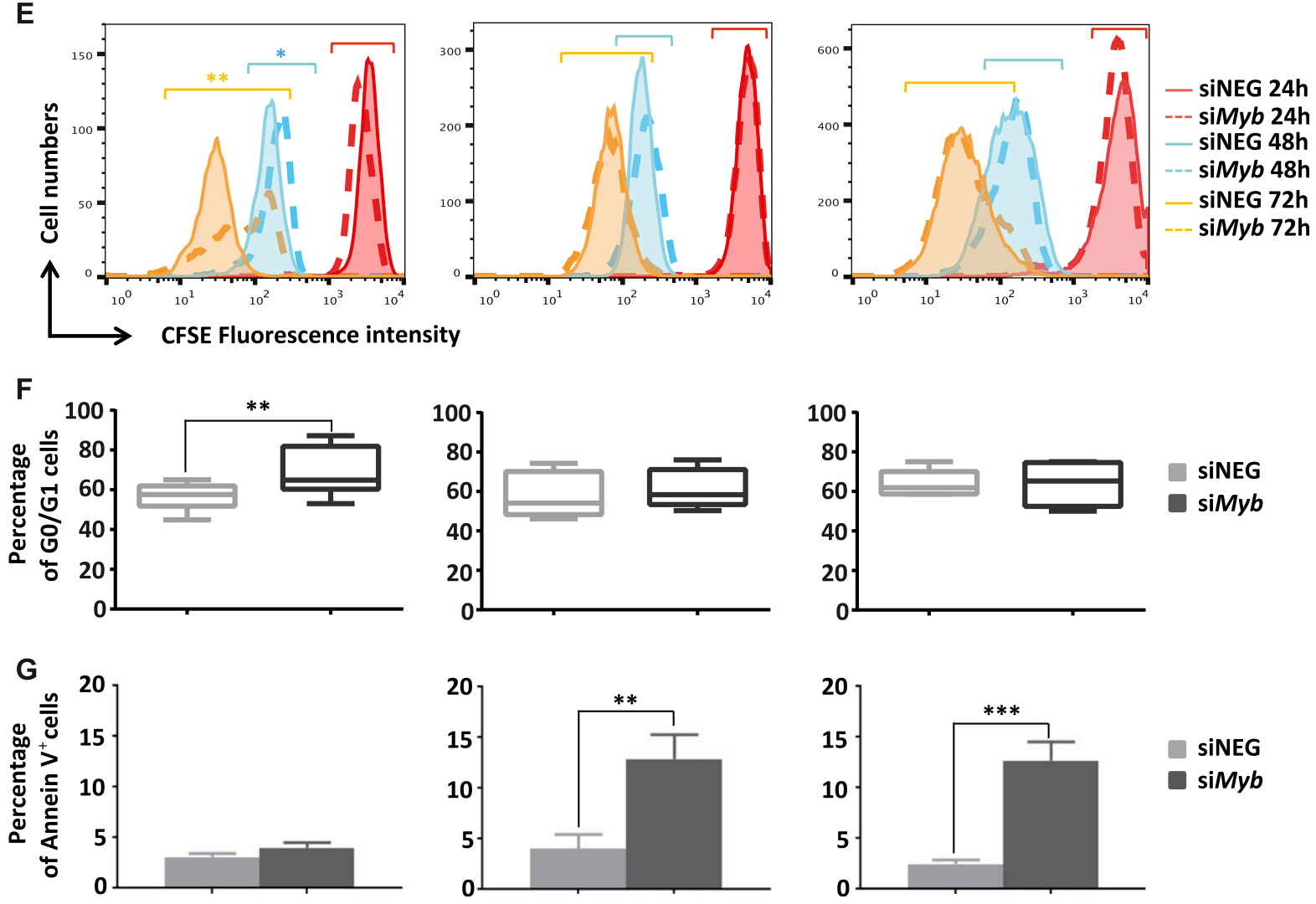
for both haematopoietic and leukaemia stem cell functions in mouse and human (Volpe et al, 2013, 2015, 2017). Using publicly available AML patient profiling arrays (Verhaak et al, 2009) and focussing on specific molecular abnormalities found in cytogenetically normal AML (CN$A M L$ ), we observed that MYB expression levels are highest in those patients carrying biallelic CEBPA mutations (Fig 1A).

Given the lack of a suitable cellular system to investigate the relationship between MYB and C/EBP $\alpha$ in human AML, we used murine cell lines modelling the spectrum of CEBPA mutations. Bereshchenko and coworkers demonstrated that mutations in the $\mathrm{C} / \mathrm{EBP} \alpha$ protein efficiently drive leukaemia in vivo and that the combination of $\mathrm{N}$ - and $\mathrm{C}$-terminal mutations were the most highly leukaemogenic, whereas biallelic C-terminal mutation resulted in the longest latency (Kirstetter et al, 2008; Bereshchenko et al, 2009). We generated cell lines by performing serial replating in semisolid medium of E14.5 foetal liver cells carrying knock-in modifications mimicking either the $\mathrm{N}$-terminal LP30 ( $\mathrm{L}$ allele) or the C-terminal K313KK (K allele) CEBPA mutations (Grebien et al, 2015). LL cells were used to represent $A M L$ harbouring biallelic N-terminal CEBPA mutations, whereas cells carrying one $\mathrm{K}$ mutation and one $\mathrm{L}$ mutation (KL cells) provided a model of leukaemia with both $\mathrm{N}$ - and C-terminal CEBPA mutations. AML with wild-type C/EBP $\alpha$ expression was modelled using a previously characterised myelomonocytic leukaemia cell line, namely, FMH9 (Volpe et al, 2013), which was established by ectopic expression of HoxA9 and Meis1 in bone marrow haematopoietic progenitor cells. The phenotype of these cells lines was investigated by determining the surface expression of several myeloid markers (CD11b, Gr1, Kit, and Flt3) (Fig S1A). Importantly, mRNA quantification indicated that both FMH9 and LL cells displayed similar Myb mRNA levels, whereas KL cells exhibited a higher level of Myb expression (Fig 1B), thus being in agreement with the observations obtained from the patient array data.

\section{Manipulation of Myb expression does not reverse the differentiation block in cells carrying biallelic $\mathrm{N}$-terminal CEBPA mutations}

To investigate the requirement for Myb in the maintenance of CEBPA-driven leukaemia, we performed siRNA-mediated knockdown of Myb. Cells were transfected with siRNAs targeting either Myb or a scrambled negative control and were harvested after $24 \mathrm{~h}$ to determine the efficiency of knockdown. This analysis revealed a decrease in Myb transcripts by $60-80 \%$ in all cell lines (Fig 1C).
To determine the biological consequences of Myb knockdown cells were cultured for up to $96 \mathrm{~h}$ and cell numbers determined daily. Myb down-regulation induced growth retardation in the three cell lines, regardless of the CEBPA mutational status; albeit those cells showing a similar pattern, the growth defect observed in FMH9 cells was significantly more pronounced in comparison with the CEBPA mutant cells lines (Figs 1D and S1B). Flow cytometric analysis of CSFE dye dilution revealed that Myb knockdown induced a significant proliferation defect in FMH9 cells, whereas both $\mathrm{KL}$ and $\mathrm{LL}$ cells were unaffected (Figs $1 \mathrm{E}$ and S1C). The pattern of the proliferation defect observed in FMH9 cells $72 \mathrm{~h}$ post Myb downregulation appeared to be bimodal, probably because of cells being induced to differentiate or due to the transient effect of the siRNAmediated knockdown. By combined staining with 7-AAD and BRDU $48 \mathrm{~h}$ post-transfection, we observed that Myb knockdown led to a significant increase in the proportion of cells in the G0/G1 phase with a concomitant decrease in both $\mathrm{S}$ and $\mathrm{G} 2 / \mathrm{M}$ phases in $\mathrm{FMH9}$, whereas $\mathrm{KL}$ and $\mathrm{LL}$ cells showed no alteration in their capacity to progress through the cell cycle (Figs $1 \mathrm{~F}$ and S2A, and B). This analysis also revealed an increase in the percentage of cells with less than 2n DNA content in CEBPA-mutant cell lines only, this being indicative of cells undergoing apoptosis/necrosis (Fig S2C). To confirm this observation, we performed Annexin $V$ staining. This revealed a significant increase in the extent of apoptotic/necrotic cells in both $\mathrm{KL}$ and $\mathrm{LL}$ cells, whereas no increase was observed in FMH9 cells (Figs $1 \mathrm{G}$ and S3A).

Because it is accepted that homozygous CEBPA mutations lead to a block in myeloid lineage commitment, we investigated how Myb knockdown affects the differentiation capacity of cells in the presence of either wild-type or biallelic mutant C/EBP $\alpha$. At $96 \mathrm{~h}$, both FMH9 and KL cells exhibited a clear induction of myeloid differentiation as indicated by increased expression of $\mathrm{Gr}-1$ and CD11b (Fig 2). However, this phenomenon was not observed in LL cells, which is intriguing because it suggests that leukaemia cells carrying biallelic $\mathrm{N}$-terminal CEBPA mutations have a reduced dependency on Myb expression in respect to differentiation control.

\section{Molecular consequences of Myb manipulation in cell lines carrying either wild-type or mutant CEBPA}

Myb was previously reported to suppress myeloid commitment and to promote self-renewal in haematopoietic progenitors and

Figure 1. Myb expression is required for the proliferation of CEBPA biallelic mutant cell lines.

(A) Scatter plot depicting the abundance of MYB transcript in subgroups of patients from the Verhaak et al (2009) dataset, characterised by the molecular abnormalities indicated in the graph. Statistical significance presented in this plot has been calculated using non-parametric the Kruskal-Wallis test. (B) Bar plot representing Myb mRNA quantification by quantitative RT-PCR in FMH9, KL, and LL cell lines, normalised against B2m house-keeping gene results. Statistical analysis was performed using $t$ test ( ${ }^{* *} P<0.01$ and ${ }^{*} P<0.05$ ). (C) Quantitative RT-PCR of Myb transcript abundance in FMH9, KL, and LL cells $24 \mathrm{~h}$ post-transfection with Myb siRNA. Expression is normalised to $B 2 \mathrm{~m}$ and standardised to the control samples. Error bars represent the SEM and numbers are plotted as mean \pm SEM. Each plot is representative of six independent experiments ( ${ }^{* \star *} P<0.001$ and $\left.{ }^{*} P<0.05\right)$. (D) Bar plot indicating the cell viability and relative proliferation of FMH9, KL, and LL cells after Myb siRNA transfection relative to the corresponding negative control ( ${ }^{* *} P<0.001$ and ${ }^{* *} P<0.01,{ }^{*} P<0.05$ ). This plot represents an average of six independent experiments. (E) Flow cytometric analysis of cellular proliferation by CFSE incorporation in FMH9, KL, and LL cells after Myb siRNA transfection relative to the corresponding negative control. Continuous lines indicate cells transfected with the negative control siRNA, whereas dashed lines indicate siMyb-transfected cells. The statistical analysis was performed using $t$ test on the geometric means of fluorescence intensity for each time point comparing siNEG versus siMyb-treated cells, as indicated by the colour-matched bar on top of every peak (** $P<0.01$ and ${ }^{*} P<0.05$ ). Each histogram is representative of six independent experiments. (F) Flow cytometric analysis of the cell cycle in FMH9, KL, and LL cells was performed by staining with 7-AAD at $48 \mathrm{~h}$ after Myb siRNA transfection and compared with the negative control. Percentages of cells in G0/G1 are indicated in each histogram. Each plot is indicative of six independent experiments. (G) Representative bar plot showing apoptosis analysis performed by Annexin $\mathrm{V}$ staining $72 \mathrm{~h}$ post Myb siRNA transfection in FMH9, KL, and LL cells ( ${ }^{* * *} P<0.001$ and $\left.{ }^{* *} P<0.01\right)$. Each bar plot represents an average of six independent experiments. 

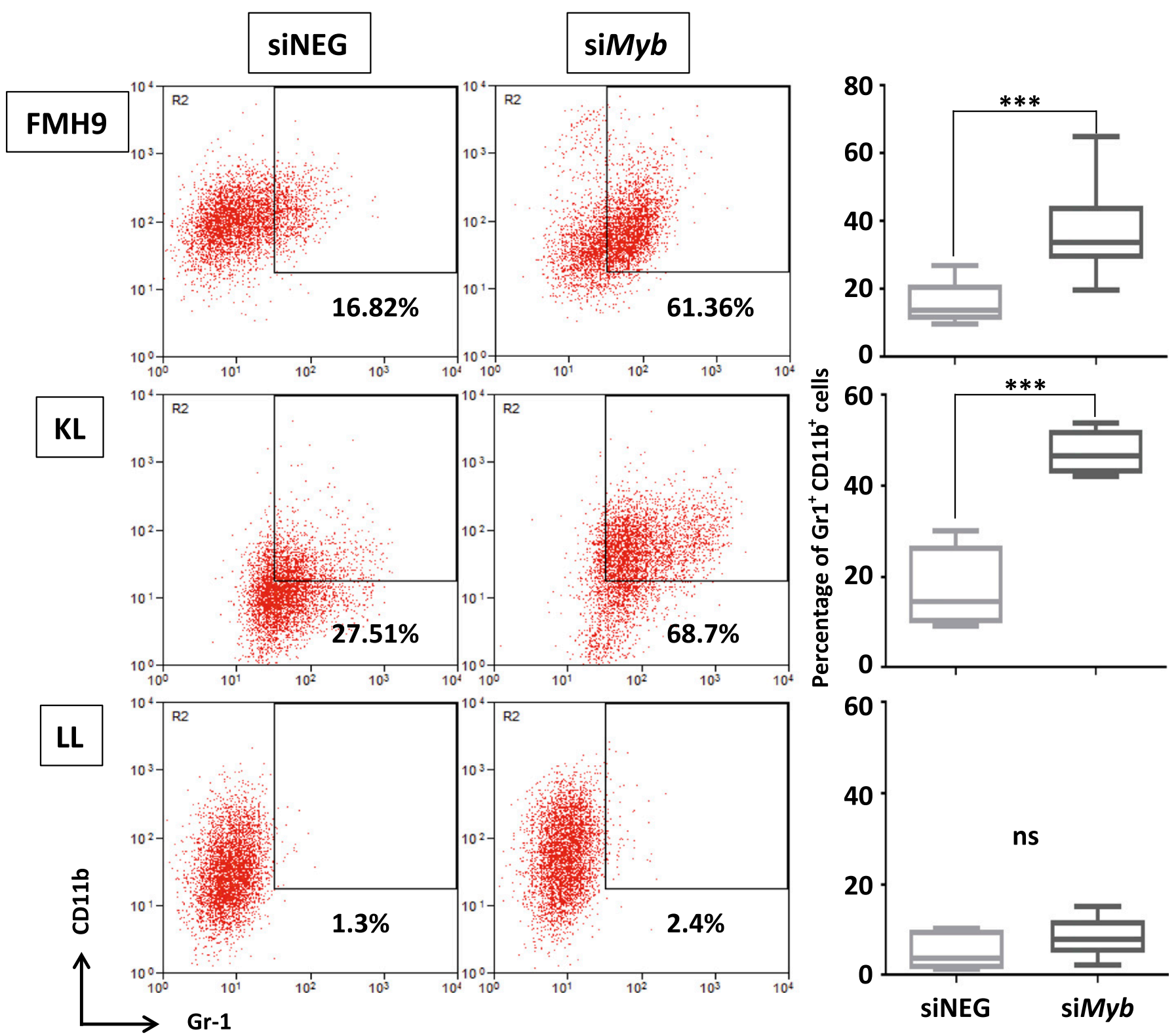

Figure 2. Suppression of Myb expression overrides myeloid differentiation block in FMH9, KL but not in LL cells.

Two-dimensional flow cytometric dot plot representing the analysis of CD11b and Gr-1 myeloid surface markers expression in FMH9, KL, and LL transfected with either Myb siRNA or the corresponding control. The percentage of double-positive cells is indicated in every plot. The box plots in the right panel shows an average of six independent experiments. Statistical significance was calculated using $t$ test $\left({ }^{* *} P<0.001\right)$.

leukaemia cells (Lorenzo et al, 2011; Zhao et al, 2011). We wished to explore how the interplay between Myb and wild-type or mutant $\mathrm{C} / \mathrm{EBP} \alpha$ influences the transcriptome, so we performed RNA-seq analysis following Myb knockdown in the context of wild-type or mutant C/EBP $\alpha$. In line with previous reports, inspection of the RNAseq datasets for FMH9, KL, and LL cells showed the expected patterns for typical myeloid genes that are known to be Myb targets, such as Gfi1, Itgam/CD11b, Gr-1/Ly6d, and Ccnd2 (Fig S4A and B).

Analysis of the RNA-seq data by global correlation clustering of fragments per kilobase of transcript per million mapped reads (FPKM) in steady-state conditions (i.e., after control siRNA treatment only) revealed higher similarity between $\mathrm{KL}$ and LL cells, with FMH9 cells clustering on their own, in line with previous reports on biallelic CEBPA mutants (Wouters et al, 2009; Taskesen et al, 2011) (Fig 3A). Differential gene expression analysis comparing control and siMyb-transfected FMH9, KL, and LL cells revealed 790, 1217, and 40 genes being down-regulated, whereas 1364, 1668, and 329 genes were up-regulated (Fig S5A). This demonstrates that, whereas FMH9 and $\mathrm{KL}$ cells display a large number of genes responsive to Myb knockdown, LL cells exhibited only minor transcriptomic responses. Intersection of the gene expression changes showed generally a greater overlap of up-regulated genes than down-regulated genes (Fig 3B), whereas hierarchical clustering revealed a higher degree of similarity between gene expression changes in $\mathrm{FMH} 9$ and $\mathrm{KL}$ cells 
A
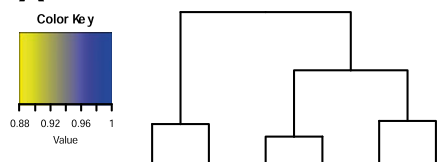

B
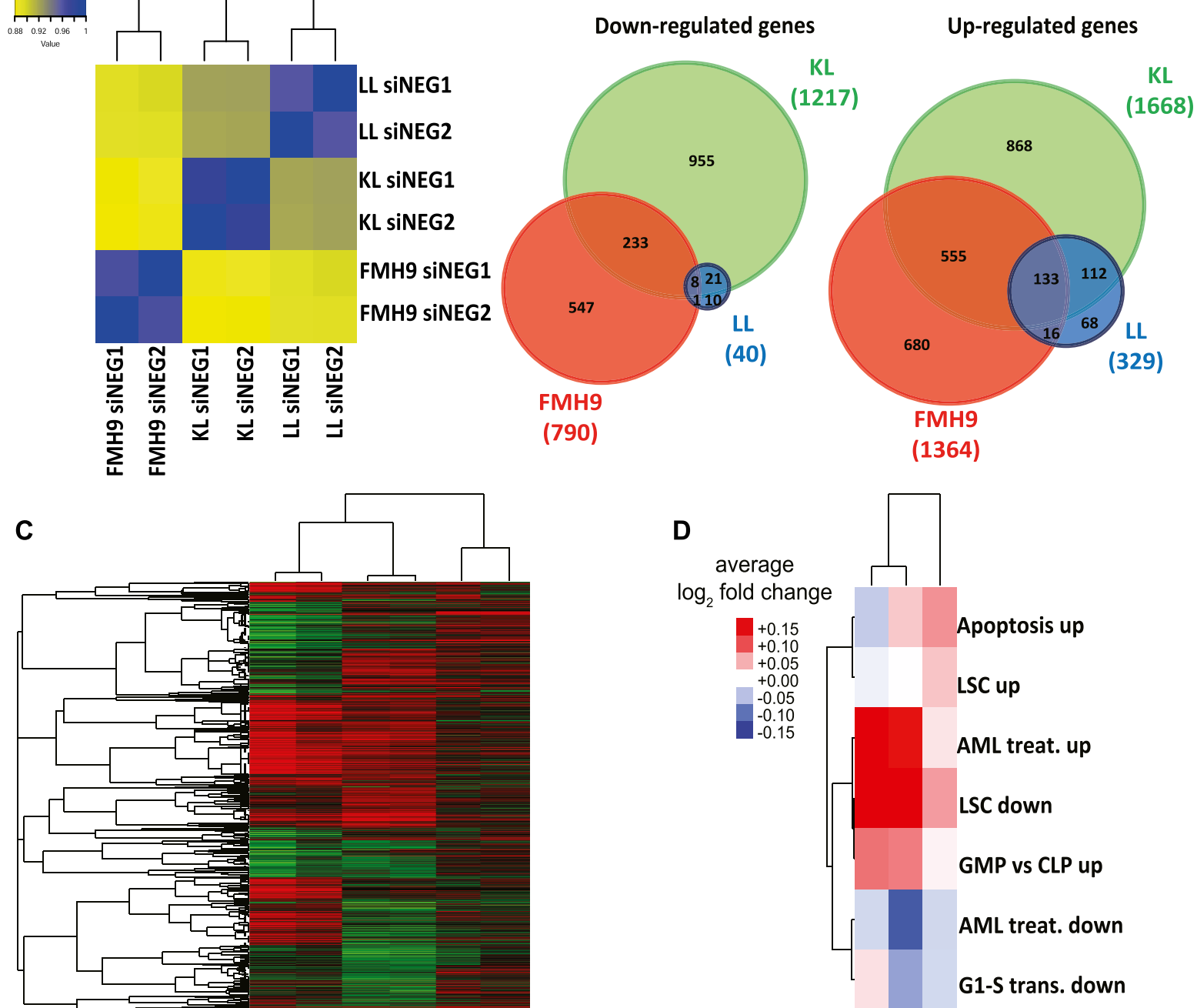

average
$\log _{2}$ fold change
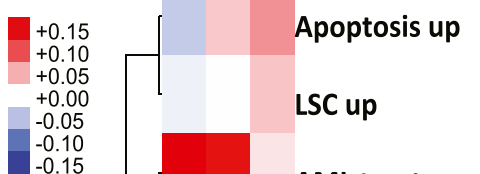

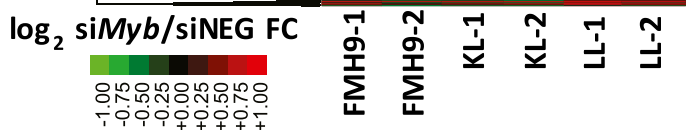
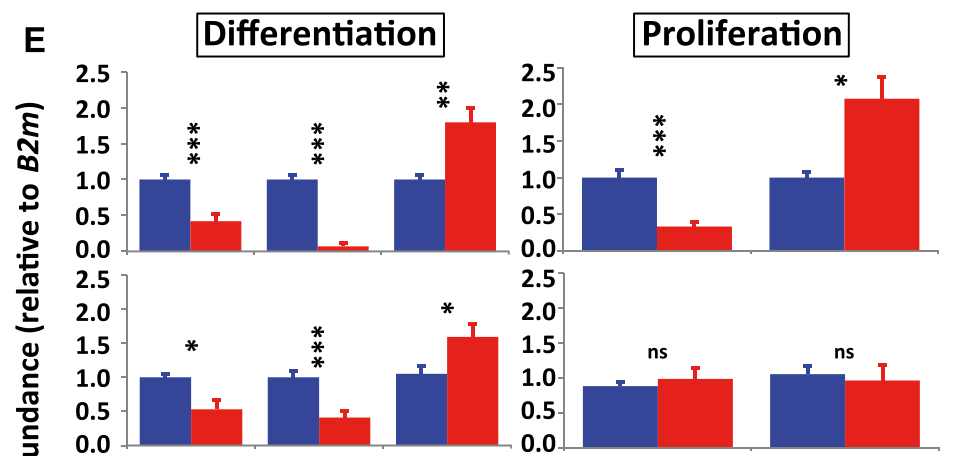

2.5
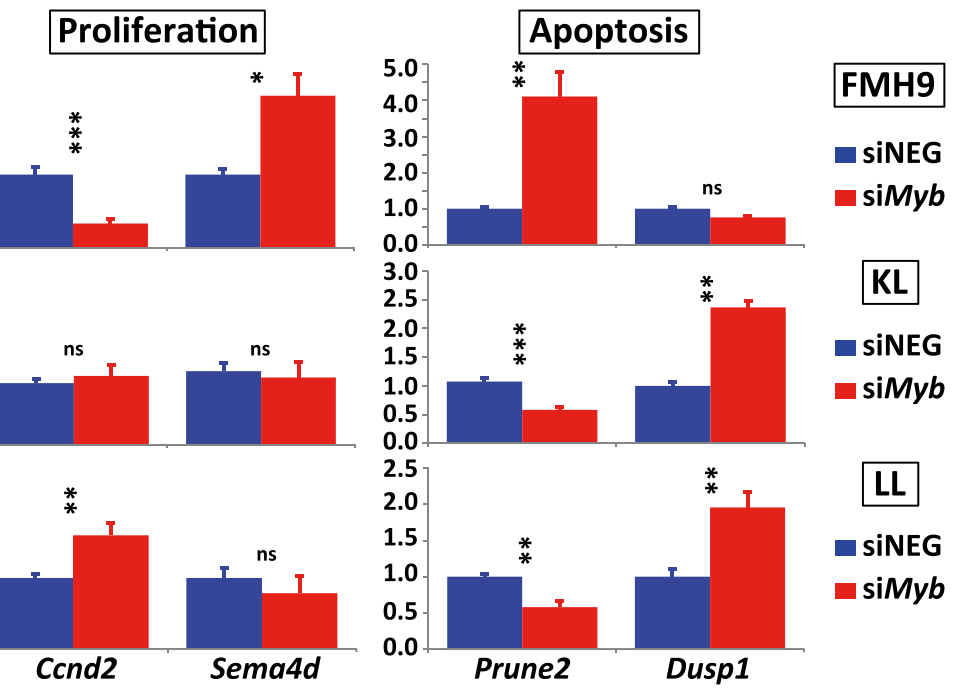
over changes observed in LL cells (Fig 3C). These findings confirm our hypothesis that the LL-mutant leukaemia phenotype is less dependent on Myb.

We next investigated whether Myb knockdown results in differential regulation of relevant gene ontologies. We examined negative regulation of $\mathrm{G} 1$ to $\mathrm{S}$ phase transition (Ashburner et al, 2000), leukaemia stem cell state (Gal et al, 2006), response to AML treatment (Bogni et al, 2006), and terminal myeloid differentiation, computing average $\log _{2}$ siMyb/control fold changes for each ontologies (Table S1). We found that FMH9 and KL cells, but not LL cells, exhibited down-regulation of the leukaemia stem cell gene expression programme following Myb knockdown (Figs 3D and S5B). Crucially, this analysis also showed that specifically for FMH9 and $\mathrm{KL}$ cells, siMyb treatment resulted in up-regulation of genes that are also up-regulated during the treatment of AML.

To confirm the observations obtained from the RNA-seq, we performed quantitative RT-PCR analysis of selected key genes. Significantly, Cebpa mRNA was down-regulated upon Myb knockdown in both FMH9 and KL cells, but not in LL cells. This suggests that the functional cross-regulation between Myb and $\mathrm{C} / \mathrm{EBP} \alpha$ could be lost in the presence of biallelic N-terminal CEBPA mutations. This analysis confirmed specific regulation by Myb of differentiation-related genes in FMH9 and KL cells but not in LL cells (Gfi1 and Sbno2), changes in the expression of genes leading to a negative impact on proliferation in FMH9 cells (Ccnd2 and Sema4d), and down- and up-regulation of genes related to increased apoptosis seen in KL and LL cells (Prune2 and Dusp1) (Figs 3E and S4B). Moreover, inspection of known Myb target genes revealed a significant repression of Bcl2 (Taylor et al, 1996; Salomoni et al, 1997), a known anti-apoptotic regulator, in $\mathrm{KL}$ cells; concomitantly, we observed the up-regulation of a pro-apoptotic gene normally anticorrelated with Myb in AML, namely, Bcl2l11 (Bim) (Jing et al, 2015), in $\mathrm{LL}$ cells. This is in agreement with the strong induction of apoptosis observed in these cells upon Myb knockdown (Fig S3A and B).

Overall, the transcriptome changes following Myb knockdown in cell lines with different CEBPA mutational status are consistent with the corresponding phenotypic changes and further demonstrate that cells with the biallelic LL C/EBP $\alpha$ configuration lack a major dependence on Myb.

\section{Coincident binding of C/EBP $\alpha$ p42 and Myb correlates with gene repression by Myb, whereas genes positively controlled by Myb tend to bind C/EBP $\alpha$ p30}

To shed light on the possible interplay between the mutational status of $\mathrm{C} / \mathrm{EBP} \alpha$ and the Myb-dependent regulation of $\mathrm{C} / \mathrm{EBP} \alpha$ target genes, we set out to investigate the chromatin binding properties and transcriptional effects of C/EBP $\alpha$ p30, C/EBP $\alpha$ p42, and K313KK-mutant C/EBP $\alpha$ isoforms. The $\mathrm{N}$-terminal-mutant $\mathrm{L}$ allele (Kirstetter et al, 2008) leads to the expression of the p30 isoform only, whereas the C/EBP $\alpha$ K313KK-mutant allele gives rise to a C-terminal mutant that disables the DNA-binding domain, resulting in a block in differentiation (Bereshchenko et al, 2009). Because the binding dynamics of $\mathrm{C} / \mathrm{EBP} \alpha$ in double-mutant cells would be technically difficult to characterise, we used previously published chromatin immunoprecipitation sequencing (ChIP-Seq) data from a single isoform transfection model (Grebien et al, 2015). This study used HA-tagged Cebpa constructs transfected into the FDCP1 cell line (Bernard et al, 1991) and an immortalised IL3dependent murine myeloid cell line that approximates to the wild-type C/EBPa leukaemia line FMH9 that we used for the Myb knockdown studies. This latter study concurrently provided gene expression microarray analysis of mock- and C/EBP $\alpha$-transfected cells. As expected, there were significant increases in Cebpa transcript abundance following overexpression of C/EBP $\alpha$ p30, C/ EBP $\alpha$ p42, and C/EBP $\alpha$ K313KK as compared with mock transfection (Fig S6A, compare with Fig S6B in FMH9, KL, and LL cells). Analysis of ChIP-seq data revealed 17,452, 22,873, and 68,432 peaks for C/EBP $\alpha$ p30-, C/EBP $\alpha$ p42-, and C/EBP $\alpha$ K313KK-transfected cells, respectively, which were mostly located in intergenic and intronic regions (Fig S6C and D). However, visual inspection of the C/EBP $\alpha$ K313KK dataset revealed low signal in K313KK peaks, hinting that those are not specific, consistent with the loss of binding due to the K313KK mutation in the DNA-binding domain (Grebien et al, 2015; Bereshchenko et al, 2009). We next characterised specific p30 and p42 peaks by ranking tag counts around merged summits by $\mathrm{p} 30 / \mathrm{p} 42$ fold change and identified 3,585 p42-specific, 19,949 shared, and 4,421 p30-specific peaks (Fig 4A). Although we did not use the C/EBPa K313KK dataset as a direct base for comparison because of the deleterious effect of the $\mathrm{K}$ allele on DNA binding, and thus low signal to noise ratio, its binding pattern was mostly located in shared sites. Crucially, by retrieving tag counts for Myb ChIP-Seq datasets, we observed that Myb binding largely parallels that of $p 42$ binding, both in FDCP1 and in an MLL-AF9/NrasG12D murine AML cell line (Roe et al, 2015), although there was an overlap with some regions that predominantly bind p30 (Fig 4A). GO analysis of the p42-specific peaks revealed signalling pathways involved in haematopoietic homeostasis and pro-apoptotic genes (Fig 4B). Conversely, p30-specific peaks were enriched in pluripotency genes, consistent with the leukaemia stem cell signature seen amongst the up-regulated genes following Myb knockdown in LL cells (Figs 3D and 4B, and S5B).

To characterise the consequences of $\mathrm{C} / \mathrm{EBP} \alpha$ binding on gene expression, we performed GSEA using microarray datasets from FDCP1 cells expressing p30, p42, and K313KK, ranking by $\log _{2}$ fold change against mock transfection. We selected gene sets corresponding to the closest genes of the top 1,000 peaks for cognate ChIP-Seq datasets (p30, p42, and K313KK) in accordance with the constraints of GSEA. We observed significant correlations between

Figure 3. Myb down-regulation causes concomitant differential regulation of leukaemia gene expression programmes in both FMH9 and KL but not LL cells. (A) Spearman correlation clustering of steady-state, control scrambled negative siRNA-transfected FMH9, KL, and LL cells. (B) Venn diagram overlaps of differentially expressed genes in FMH9, KL, and LL cell lines following Myb knockdown. Left and right: significantly down- and up-regulated genes, respectively. (C) Hierarchical clustering of $\log _{2}$ fold changes resulting from siMyb treatment in FMH9, KL, and LL cells. (D) Average siMyb/siNEG log, fold changes for leukaemia-relevant GO classes. (E) RT-qPCR gene expression analysis of differentiation, apoptosis, and cell cycle genes post control and siMyb transfection. Relative expression values are presented as \pm SEM. Statistical analysis was performed using $t$ test $\left({ }^{* * *} P<0.001,{ }^{* \star} P<0.01\right.$, and $\left.{ }^{\star} P<0.05\right)$. Each bar plot represents an average of six independent experiments. 


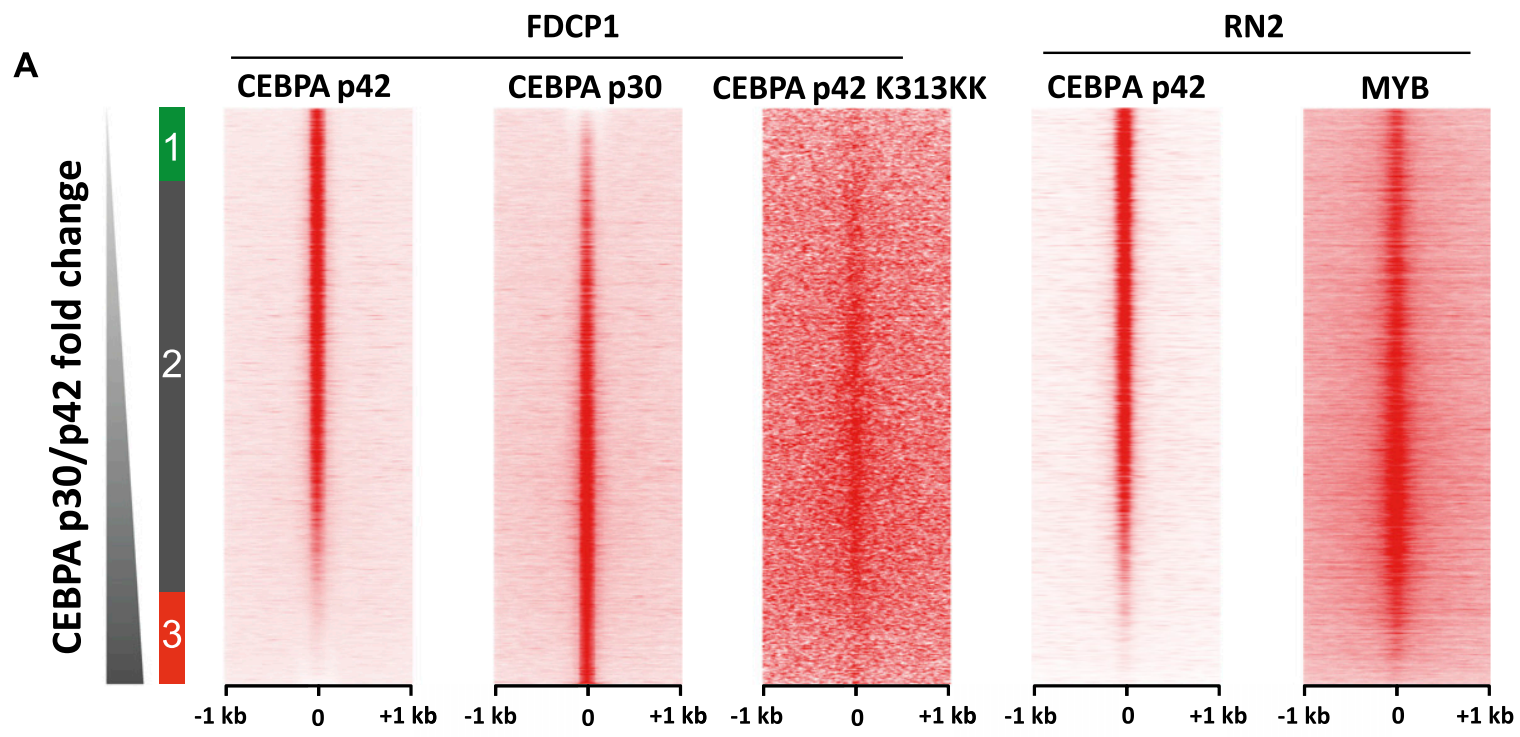

B

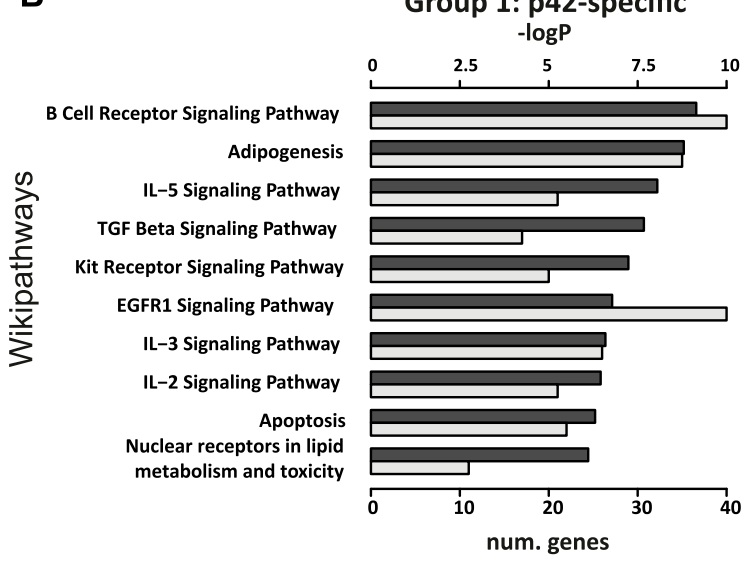

Group 3: p30-specific

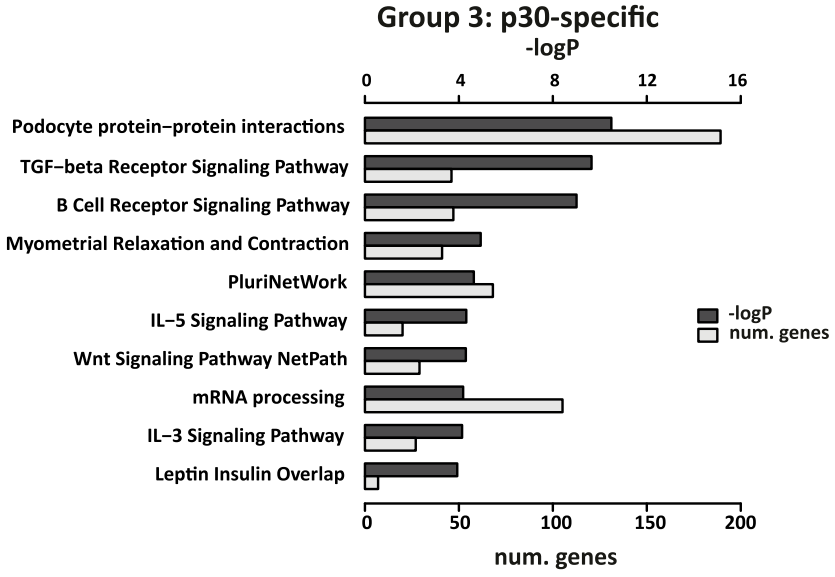

D

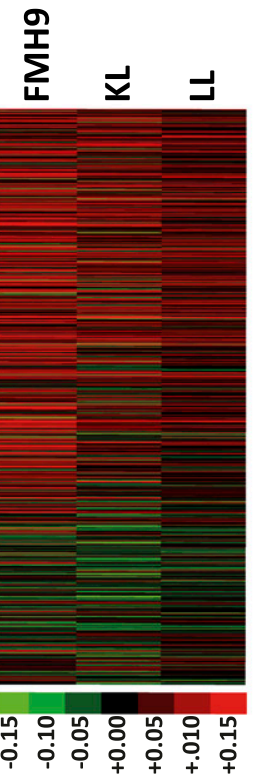

E

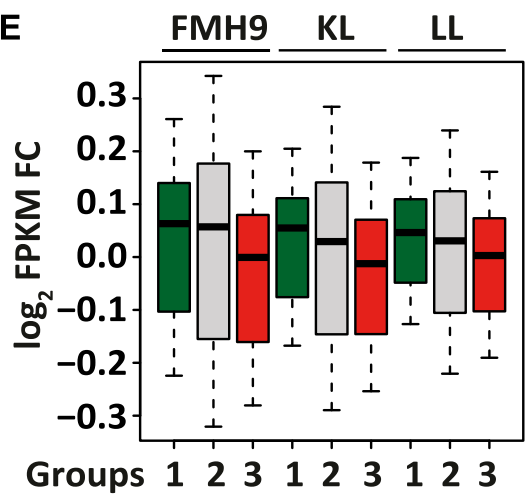

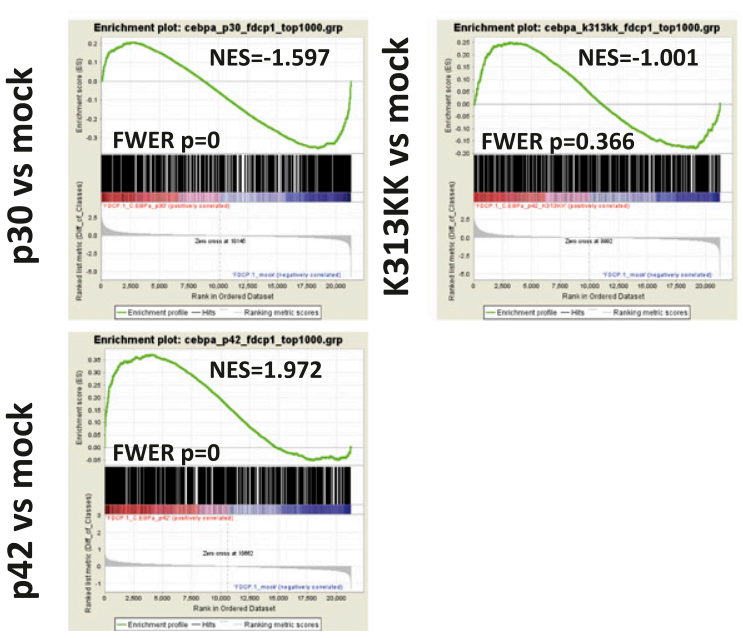


p42-induced gene activation and p42 binding, as well as between p30-induced gene repression and p30 binding (Fig 4C). However, $\mathrm{C} / \mathrm{EBP} \alpha \mathrm{K} 313 \mathrm{KK}$ binding was not correlated with changes in gene expression.

We next asked how C/EBP $\alpha$ isoform binding correlates with genes whose expression is altered by Myb knockdown. We plotted gene expression fold changes caused by Myb knockdown in FMH9, $\mathrm{KL}$, and $\mathrm{LL}$ cells against the ChIP-seq data ranking of $\mathrm{p30/p42}$ binding. Two broad conclusions arise from this analysis: first, Myb-repressed genes largely bound $\mathrm{p} 42$ in the presence or absence of p30; second, genes that are positively regulated by Myb are more predominant amongst the group of genes that preferentially bind p30 (Fig 4D and E). Conversely, p30 binding was linked with downregulation of gene expression upon Myb knockdown.

We next investigated the sequence content of p30- and p42specific sites by performing motif discovery analysis in the sequences corresponding to these peaks. This revealed that C/EBP, AP-1, Ets, Myb, and Runx motifs were highly enriched in p42-specific peaks (Fig S7A). However, the C/EBP motif was not enriched in the p30-specific peaks. Instead, these peaks were enriched in CTCF, Nrf, and Ets motifs. To confirm these trends, we plotted motif matches amongst increasing p30/p42 fold change as above. Strikingly, C/EBP motifs seemed to be restricted to p42-specific and shared sites (Fig S7B). Myb, Runx, AP-1, and Ets motifs also followed this trend. Conversely, CTCF motifs were highly enriched in p30-specific sites and to some extent in shared sites corresponding to lower p42 binding. Nrf, Sp1, and CREB motifs also seemed to follow this trend, but not Elf motifs. To verify binding of cognate factors to these motifs as well as active and inactive transcriptional hallmarks, we made use of publicly available AML ChIP-Seq datasets (Yue et al, 2014; Roe et al, 2015). Our analysis revealed that C/EBP $\beta$, an essential transcription factor in normal myeloid development (Goode et al, 2016), which is able to bind C/EBP motifs as well, also colocalised with p42 (Fig S7C). Furthermore, by retrieving tag counts for the transcription activation hallmark p300, we could also show that p42-specific and shared sites, but not p30-specific sites, correspond to putative enhancer sites, consistent with our GSEA analyses for this isoform (Figs $4 \mathrm{C}$ and S7D).

\section{Discussion}

In the present study, we have investigated the requirement for the transcription factor Myb in the maintenance of CN-AML driven by different combinations of CEBPA mutations in comparison with leukaemia characterised by the expression of wild-type C/EBP $\alpha$. We show for the first time that the dependency on Myb is affected by the mutational status of $\mathrm{C} / \mathrm{EBP} \alpha$. Compared with cells expressing wild-type $\mathrm{C} / \mathrm{EBP} \alpha$, which show a proliferation and differentiation response to enforced reduction in Myb levels, leukaemia driven by biallelic CEBPA mutations exhibits distinct phenotypic responses that are reflected in changes in gene expression. Furthermore, leukaemia with biallelic $\mathrm{N}^{\text {ter }} / \mathrm{N}^{\text {ter }}$ CEBPA mutations shows a reduced dependency on Myb, whereas $C^{\text {ter }} / N^{\text {ter }}$ mutant-driven AML cells are as reliant on Myb as those expressing wild-type C/EBP $\alpha$ but exhibit a quite distinct pattern of phenotype and gene expression changes upon Myb knockdown.

Here, we show that knockdown of Myb in leukaemia cells harbouring either wild-type or $\mathrm{C}^{\text {ter }} / \mathrm{N}^{\text {ter }}$-mutant $\mathrm{C} / \mathrm{EBP} \alpha$ reverses the abnormal myeloid phenotype normally observed in leukaemia, whereas AML cells carrying biallelic $N^{\text {ter }} / N^{\text {ter }}$ mutations exhibit persistence of the undifferentiated phenotype. These behaviours are reflected in distinct changes in gene expression. Hence, Myb knockdown in leukaemia cells with wild-type or $\mathrm{C}^{\text {ter }} / \mathrm{N}^{\text {ter }}$-mutant $\mathrm{C} / \mathrm{EBP} \alpha$ resulted in the loss of a leukaemia stem cell signature and the up-regulation of a gene expression pattern generally observed in patients that are responding to therapeutic treatment. In line with previous reports (Zhao et al, 2014), our analysis demonstrated Gfi1 and Sbno2, both of which encode transcription factors that can be related to the loss of differentiation block, to be positive and negative targets of Myb activity, respectively. The reduced dependency of $\mathrm{N}^{\text {ter }} / \mathrm{N}^{\text {ter }}$-mutant C/EBP $\alpha$-driven $\mathrm{AML}$ cells on Myb is also paralleled by very little change in the number of genes affected by Myb knockdown, including no effect on Gi1 or Sbno2. Interestingly, Myb targets the expression of the Cebpa gene itself in the wild-type and $C^{\text {ter }} / N^{\text {ter }} \mathrm{C} / \mathrm{EBP} \alpha$ contexts, suggesting positive feedback that is not seen in C/EBP $\alpha \mathrm{N}^{\text {ter }} / \mathrm{N}^{\text {ter }}$ cells. This result might provide a hint why LL leukaemia displays a different response to Myb manipulation. Analysis of cell cycle and apoptosis also revealed how knockdown of Myb can lead to quite a distinct phenotype; for instance, although no induction in apoptosis/ necrosis was observed in $\mathrm{C} / \mathrm{EBP} \alpha$ wild-type cells, both mutant cell lines displayed a large increase in the percentage of Annexin $\mathrm{V}^{+}$ cells and the appearance of a sub2n population, which is indicative of cells undergoing cell death. However, it is possible that other biological pathways could be affected that lead to such a different response, with the cells perhaps being forced to engage in nonapoptotic fates, such as necroptosis, autophagic cell death, or pyroptosis (Tait et al, 2014); these possibilities remain to be further elucidated.

Considering the different involvement of p30 and p42 in the three leukaemia scenarios we have investigated, the fact that there are p42-only- and p30-only-bound genes indicates that a distinct response should be expected when Myb is reduced, especially when only p30 is present. Most p42- or p42+p30-binding genes also bind Myb, but interestingly, a significant number of p30-only target genes probably do not bind Myb. The genes that bound predominantly $\mathrm{p} 42$ fall into $\mathrm{GO}$ groups, including those associated with

Figure 4. p42 C/EBP $\alpha$ binding is linked with gene activation increased following Myb knockdown, whereas p30 C/EBP $\alpha$ binding correlates with gene repression independently of Myb.

(A) Heat maps sorted by C/EBP $\alpha$ p30/p42 tag count fold change of ChIP-seq signals for C/EBP $\alpha$ p42, C/EBP $\alpha$ p42 K313KK, and C/EBP $\alpha$ p30 isoforms in the FDCP1 cell line, as well as for Myb and C/EBP $\alpha$ p42 in the RN2 cell line. (B) GO analyses of p42 and p30 C/EBP $\alpha$-specific peaks (left, right). (C) Gene set enrichment analyses of C/EBP $\alpha$ p30, C/EBP $\alpha$ p42, and C/EBP $\alpha$ p42-K313KK binding versus cognate-induced fold change (top left, top right, and bottom left, respectively). (A, D) Heat map showing siMyb/siNEG gene expression fold change in FMH9, KL, and LL cells sorted by C/EBP $\alpha$ p30/p42 ChIP-seq tag count fold change as in (A). (A, D, E) Box plots showing quantification of gene expression fold changes from (D) for the nearest genes from groups 1, 2, and 3 defined in (A). Means indicated. 
myeloid homeostasis and differentiation, consistent with the finding that Myb knockdown restores myeloid differentiation. Conversely, but in agreement with a persisting leukaemia phenotype not being affected by Myb manipulation, genes bound by $\mathrm{p} 30$ include pluripotency genes. This is in line with a previous report that mature cells can tap into stem cell regulatory networks when experiencing mutational hits in key differentiation factors (Soucie et al, 2016).

The vast majority of genes affected by Myb knockdown in the context of $\mathrm{N}^{\text {ter }} / \mathrm{N}^{\text {ter }}$ biallelic-mutant C/EBP $\alpha$ are de-repressed and overlap with genes similarly affected in the context of $\mathrm{C}^{\text {ter }} / \mathrm{N}^{\text {ter }}$. That genes such as Dusp1 are not responsive to Myb changes in the context of wild-type C/EBP $\alpha$ presumably means that $\mathrm{p} 42$, being fully competent to dimerise and bind DNA is less dependent on Myb. Mapping these gene expression changes onto the profile of $\mathrm{p} 42$ / p30 binding revealed that they can be expected normally to bind both p42 and p30. The large number of genes affected by Myb knockdown that distinguished the response of $\mathrm{C}^{\text {ter }} / \mathrm{N}^{\text {ter }}$ from $\mathrm{N}^{\text {ter }} /$ $N^{\text {ter }}$ are both down-regulated (1,188 genes) and up-regulated (1,423 genes), the majority of the former corresponding to genes that are preferentially bound by $\mathrm{p} 30$. In contrast, the up-regulated genes, normally repressed by Myb as seen in the $\mathrm{N}^{\text {ter }} / \mathrm{N}^{\text {ter }}$ situation, tend to be genes that exhibit greater binding by $\mathrm{p} 42$ when it is present. Intriguingly, in the $\mathrm{N}^{\text {ter }} / \mathrm{N}^{\text {ter }}$ situation, in which most of the genes affected by Myb knockdown reflect loss of Myb-dependent repression, these genes also fall into the category of preferential binding to $\mathrm{p} 42$. Because no $\mathrm{p} 42$ is present in the $\mathrm{N}^{\text {ter }} / \mathrm{N}^{\text {ter }}$ leukaemia, this must mean that such genes can be regulated by Myb without a prerequisite for cooperation with $\mathrm{C} / \mathrm{EBP} \alpha \mathrm{p} 42$ or alternatively that another C/EBP family protein such as C/EBP $\beta$ can act in place of $C / E B P \alpha$. In this circumstance, the profile of C/EBP $\beta$ binding to genes in the context of myeloid leukaemia cells parallels that of $\mathrm{C} / \mathrm{EBP} \alpha$ p42. The consequence of this is that most of the genes bound by $\mathrm{C} / \mathrm{EBP} \alpha \mathrm{p} 42$ that are Myb dependent would not exhibit such redundancy of C/EBP protein requirement.

By analysing the occurrence of transcription factor consensus binding motifs in the sequence content of the C/EBP $\alpha$ ChIP-seq peaks, we observed that the regulatory network maintaining the different leukaemia statuses involves different possible sets of transcription factor binding. p42-specific peaks are enriched in C/EBP, Ap1, Myb, Ets, and Runx motifs, whereas the p30-specific peaks contain mostly CTCF, Nrf, and Ets motifs. Importantly, we also observed that p42-specific peaks that are also bound by Myb are highly enriched in the transcription activation hallmark p300. This is to be expected as p300 has been demonstrated to be one of the most important cofactors for Myb and the inhibition of the Myb/ p300 interaction is crucial for the maintenance of the leukaemia state (Pattabiraman et al, 2014). The same analysis performed for the p30-specific peaks revealed those sites may be enriched for CTCF in cells that do not express CEBP $\alpha$ p42 (Fig S7D).

In conclusion, we have shown that the nature of mutations in one transcription factor that drives leukaemia can dictate how another leukaemia-associated oncoprotein affects the maintenance of the leukaemia phenotype. The precise nature of the interactions between C/EBP $\alpha$ or its mutated variants and the Myb protein on specific genes that dictate the leukaemia phenotype remain to be elucidated, and it would be fruitful to assess in more detail the relevance of this interaction in human leukaemia patients harbouring those mutations. Added complexity in the involvement of C/EBP proteins in determining the Myb dependency of a given leukaemia most likely goes beyond solely the balance of the C/EBP $\alpha$ isoforms, especially given the possibility that co-expressed factors such as C/EBP $\beta$ might compete for binding to C/EBP motifs and heterodimerise with $\mathrm{C} / \mathrm{EBP} \alpha$. Ultimately, our findings call for a larger study to determine how manipulating MYB would impact on the maintenance of both murine and human leukaemia driven by other genetic lesions.

\section{Supplementary Information}

Supplementary Information is available at https://doi.org/10.26508/lsa. 201800207.

\section{Acknowledgements}

The work was supported by a Bloodwise Programme Grant (12010) held by J Frampton, S Dumon, and P Garcia and through funding provided by the College of Medical and Dental Sciences of the University of Birmingham. This project has received funding from the European Research Council under the European Union's Horizon 2020 research and innovation programme (grant agreement no. $636855 /$ StG to F Grebien)

\section{Authors Contributions}

G Volpe: conceptualisation, data curation, investigation, and writing-original draft.

P Cauchy: data curation, formal analysis, and writing-original draft. DS Walton: investigation.

C Ward: formal analysis.

D Blakemore: investigation.

R Bayley: investigation.

ML Clarke: investigation.

L Schmidt: investigation.

C Nerlov: resources

P Garcia: funding acquisition and writing-review and editing.

S Dumon: conceptualisation, supervision, and funding acquisition. F Grebien: conceptualisation, formal analysis, investigation, and writing-review and editing.

J Frampton: conceptualisation, supervision, funding acquisition, project administration, and writing-review and editing.

\section{Conflict of Interest Statement}

The authors declare no conflicts of interest.

\section{References}

Ashburner M, Ball CA, Blake JA, Botstein D, Butler H, Cherry JM, Davis AP, Dolinski K, Dwight SS, Eppig JT, et al (2000) Gene ontology: Tool for the unification of biology. The gene ontology consortium. Nat Genet 25: 25-29. doi:10.1038/75556 
Bayley R, Blakemore D, Cancian L, Dumon S, Volpe G, Ward C, Almaghrabi R, Gujar J, Reeve N, Raghavan M, et al (2018) MYBL2 supports DNA double strand break repair in hematopoietic stem cells. Cancer Res 78: 5767-5779. doi:10.1158/0008-5472.CAN-18-0273

Bereshchenko O, Mancini E, Moore S, Bilbao D, Mansson R, Luc S, Grover A, Jacobsen SE, Bryder D, Nerlov C (2009) Hematopoietic stem cell expansion precedes the generation of committed myeloid leukemiainitiating cells in C/EBPalpha mutant AML. Cancer Cell 16: 390-400. doi:10.1016/j.ccr.2009.09.036

Bernard O, Li M, Reid HH (1991) Expression of two different forms of fibroblast growth factor receptor 1 in different mouse tissues and cell lines. Proc Natl Acad Sci U S A 88: 7625-7629. doi:10.1073/pnas.88.17.7625

Bogni A, Cheng C, Liu W, Yang W, Pfeffer J, Mukatira S, French D, Downing JR, Pui CH, Relling MV (2006) Genome-wide approach to identify risk factors for therapy-related myeloid leukemia. Leukemia 20: 239-246. doi:10.1038/sj.leu.2404059

Clarke M, Volpe G, Sheriff L, Walton D, Ward C, Wei W, Dumon S, Garcia P, Frampton J (2017) Transcriptional regulation of SPROUTY2 by MYB influences myeloid cell proliferation and stem cell properties by enhancing responsiveness to IL-3. Leukemia 31: 957-966. doi:10.1038/ leu.2016.289

Dufour A, Schneider F, Metzeler KH, Hoster E, Schneider S, Zellmeier E, Benthaus T, Sauerland MC, Berdel WE, Buchner T, et al (2010) Acute myeloid leukemia with biallelic CEBPA gene mutations and normal karyotype represents a distinct genetic entity associated with a favorable clinical outcome. J Clin Oncol 28: 570-577. doi:10.1200/ jco.2008.21.6010

Fasan A, Haferlach C, Alpermann T, Jeromin S, Grossmann V, Eder C, Weissmann S, Dicker F, Kohlmann A, Schindela S, et al (2014) The role of different genetic subtypes of CEBPA mutated AML. Leukemia 28 : 794-803. doi:10.1038/leu.2013.273

Gal H, Amariglio N, Trakhtenbrot L, Jacob-Hirsh J, Margalit O, Avigdor A, Nagler A, Tavor S, Ein-Dor L, Lapidot T, et al (2006) Gene expression profiles of AML derived stem cells; similarity to hematopoietic stem cells. Leukemia 20: 2147-2154. doi:10.1038/sj.leu.2404401

Gombart AF, Hofmann WK, Kawano S, Takeuchi S, Krug U, Kwok SH, Larsen RJ, Asou H, Miller CW, Hoelzer D, et al (2002) Mutations in the gene encoding the transcription factor CCAAT/enhancer binding protein alpha in myelodysplastic syndromes and acute myeloid leukemias. Blood 99: 1332-1340. doi:10.1182/blood.v99.4.1332

Goode DK, Obier N, Vijayabaskar MS, Lie ALM, Lilly AJ, Hannah R, Lichtinger M, Batta K, Florkowska M, Patel R, et al (2016) Dynamic gene regulatory networks drive hematopoietic specification and differentiation. Dev Cell 36: 572-587. doi:10.1016/j.devcel.2016.01.024

Grebien F, Vedadi M, Getlik M, Giambruno R, Grover A, Avellino R, Skucha A, Vittori S, Kuznetsova E, Smil D, et al (2015) Pharmacological targeting of the Wdr5-MLL interaction in C/EBPalpha N-terminal leukemia. Nat Chem Biol 11: 571-578. doi:10.1038/nchembio.1859

Hess JL, Bittner CB, Zeisig DT, Bach C, Fuchs U, Borkhardt A, Frampton J, Slany RK (2006) C-Myb is an essential downstream target for homeoboxmediated transformation of hematopoietic cells. Blood 108: 297-304. doi:10.1182/blood-2005-12-5014

Jing D, Bhadri VA, Beck D, Thoms JA, Yakob NA, Wong JW, Knezevic K, Pimanda JE, Lock RB (2015) Opposing regulation of BIM and BCL2 controls glucocorticoid-induced apoptosis of pediatric acute lymphoblastic leukemia cells. Blood 125: 273-283. doi:10.1182/blood-2014-05-576470

Kelly LM, Gilliland DG (2002) Genetics of myeloid leukemias. Annu Rev Genomics Hum Genet 3: 179-198. doi:10.1146/annurev.genom.3.032802.115046

Kirstetter P, Schuster MB, Bereshchenko O, Moore S, Dvinge H, Kurz E, Theilgaard-Monch K, Mansson R, Pedersen TA, Pabst T, et al (2008) Modeling of C/EBPalpha mutant acute myeloid leukemia reveals a common expression signature of committed myeloid leukemiainitiating cells. Cancer Cell 13: 299-310. doi:10.1016/j.ccr.2008.02.008
Koschmieder S, Halmos B, Levantini E, Tenen DG (2009) Dysregulation of the C/EBPalpha differentiation pathway in human cancer. J Clin Oncol 27: 619-628. doi:10.1200/jco.2008.17.9812

Leroy H, Roumier C, Huyghe P, Biggio V, Fenaux P, Preudhomme C (2005) CEBPA point mutations in hematological malignancies. Leukemia 19: 329-334. doi:10.1038/sj.leu.2403614

Lin FT, MacDougald OA, Diehl AM, Lane MD (1993) A 30-kDa alternative translation product of the CCAAT/enhancer binding protein alpha message: Transcriptional activator lacking antimitotic activity. Proc Natl Acad Sci U S A 90: 9606-9610. doi:10.1073/pnas.90.20.9606

Lorenzo PI, Brendeford EM, Gilfillan S, Gavrilov AA, Leedsak M, Razin SV, Eskeland R, Saether T, Gabrielsen OS (2011) Identification of c-Myb target genes in $\mathrm{K} 562$ cells reveals a role for c-Myb as a Master regulator. Genes Cancer 2: 805-817. doi:10.1177/1947601911428224

Moore MA (2005) Converging pathways in leukemogenesis and stem cell selfrenewal. Exp Hematol 33: 719-737. doi:10.1016/j.exphem.2005.04.011

Nerlov C (2004) C/EBPalpha mutations in acute myeloid leukaemias. Nat Rev Cancer 4: 394-400. doi:10.1038/nrc1363

Pabst T, Mueller BU (2007) Transcriptional dysregulation during myeloid transformation in AML. Oncogene 26: 6829-6837. doi:10.1038/sj. onc. 1210765

Pabst T, Mueller BU, Zhang P, Radomska HS, Narravula S, Schnittger S, Behre G, Hiddemann W, Tenen DG (2001) Dominant-negative mutations of CEBPA, encoding CCAAT/enhancer binding protein-alpha (C) EBPalpha), in acute myeloid leukemia. Nat Genet 27: 263-270. doi:10.1038/85820

Pattabiraman DR, McGirr C, Shakhbazov K, Barbier V, Krishnan K, Mukhopadhyay P, Hawthorne P, Trezise A, Ding J, Grimmond SM, et al (2014) Interaction of c-Myb with p300 is required for the induction of acute myeloid leukemia (AML) by human AML oncogenes. Blood 123: 2682-2690. doi:10.1182/blood-2012-02-413187

Porse BT, Bryder D, Theilgaard-Monch K, Hasemann MS, Anderson K, Damgaard I, Jacobsen SE, Nerlov C (2005) Loss of C/EBP alpha cell cycle control increases myeloid progenitor proliferation and transforms the neutrophil granulocyte lineage. J Exp Med 202: 85-96. doi:10.1084/jem.20050067

Porse BT, Pedersen TA, Xu X, Lindberg B, Wewer UM, Friis-Hansen L, Nerlov C (2001) E2F repression by C/EBPalpha is required for adipogenesis and granulopoiesis in vivo. Cell 107: 247-258. doi:10.1016/s00928674(01)00516-5

Renneville A, Boissel N, Gachard N, Naguib D, Bastard C, de Botton S, Nibourel O, Pautas C, Reman O, Thomas X, et al (2009) The favorable impact of CEBPA mutations in patients with acute myeloid leukemia is only observed in the absence of associated cytogenetic abnormalities and FLT3 internal duplication. Blood 113: 5090-5093. doi:10.1182/blood2008-12-194704

Roe JS, Mercan F, Rivera K, Pappin DJ, Vakoc CR (2015) BET bromodomain inhibition suppresses the function of hematopoietic transcription factors in acute myeloid leukemia. Mol Cell 58: 1028-1039. doi:10.1016/ j.molcel.2015.04.011

Rosenbauer F, Tenen DG (2007) Transcription factors in myeloid development: Balancing differentiation with transformation. Nat Rev Immunol 7: 105-117. doi:10.1038/nri2024

Salomoni P, Perrotti D, Martinez R, Franceschi C, Calabretta B (1997) Resistance to apoptosis in CTLL-2 cells constitutively expressing c-Myb is associated with induction of BCL-2 expression and Mybdependent regulation of bcl-2 promoter activity. Proc Natl Acad Sci U S A 94: 3296-3301. doi:10.1073/pnas.94.7.3296

Schmidt L, Heyes E, Scheiblecker L, Eder T, Volpe G, Frampton J, Nerlov C, Valent P, Grembecka J, Grebien F (2019) CEBPA-mutated leukemia is sensitive to genetic and pharmacological targeting of the MLL1 complex. Leukemia. doi:10.1038/s41375-019-0382-3. 
Song G, Wang L, Bi K, Jiang G (2015) Regulation of the C/EBPalpha signaling pathway in acute myeloid leukemia (Review). Oncol Rep 33: 2099-2106. doi:10.3892/or.2015.3848

Soucie EL, Weng Z, Geirsdottir L, Molawi K, Maurizio J, Fenouil R, MossadeghKeller N, Gimenez G, VanHille L, Beniazza M, et al (2016) Lineagespecific enhancers activate self-renewal genes in macrophages and embryonic stem cells. Science 351: aad5510. doi:10.1126/science. aad5510

Tait SW, Ichim G, Green DR (2014) Die another way: Non-apoptotic mechanisms of cell death. J Cel Sci 127: 2135-2144. doi:10.1242/ jcs.093575

Taskesen E, Bullinger L, Corbacioglu A, Sanders MA, Erpelinck CA, Wouters BJ, van der Poel-van de Luytgaarde SC, Damm F, Krauter J, Ganser A, et al (2011) Prognostic impact, concurrent genetic mutations, and gene expression features of AML with CEBPA mutations in a cohort of 1182 cytogenetically normal AML patients: Further evidence for CEBPA double mutant AML as a distinctive disease entity. Blood 117: 2469-2475. doi:10.1182/blood-2010-09-307280

Taylor D, Badiani P, Weston K (1996) A dominant interfering Myb mutant causes apoptosis in T cells. Genes Dev 10: 2732-2744. doi:10.1101/ gad.10.21.2732

Tenen DG (2003) Disruption of differentiation in human cancer: AML shows the way. Nat Rev Cancer 3: 89-101.doi:10.1038/nrc989

Verhaak RG, Wouters BJ, Erpelinck CA, Abbas S, Beverloo HB, Lugthart S, Lowenberg B, Delwel R, Valk PJ (2009) Prediction of molecular subtypes in acute myeloid leukemia based on gene expression profiling. Haematologica 94: 131-134. doi:10.3324/ haematol.13299

Volpe G, Clarke M, Garcia P, Walton DS, Vegiopoulos A, Del Pozzo W, O'Neill LP, Frampton J, Dumon S (2015) Regulation of the Flt3 gene in haematopoietic stem and early progenitor cells. PLoS One 10: e0138257. doi:10.1371/journal.pone. 0138257

Volpe G, Walton DS, Del Pozzo W, Garcia P, Dasse E, O'Neill LP, Griffiths M, Frampton J, Dumon S (2013) C/EBPalpha and MYB regulate FLT3 expression in AML. Leukemia 27: 1487-1496. doi:10.1038/leu.2013.23

Volpe G, Walton DS, Grainger DE, Ward C, Cauchy P, Blakemore D, Coleman DJL, Cockerill PN, Garcia P, Frampton J (2017) Prognostic significance of high GFI1 expression in AML of normal karyotype and its association with a FLT3-ITD signature. Sci Rep 7: 11148. doi:10.1038/s41598-017-11718-8

Welner RS, Bararia D, Amabile G, Czibere A, Benoukraf T, Bach C, Wansa KD, Ye $M$, Zhang $\mathrm{H}$, lino $\mathrm{T}$, et al (2013) C/EBPalpha is required for development of dendritic cell progenitors. Blood 121: 4073-4081. doi:10.1182/ blood2012-10-463448

Wouters BJ, Lowenberg B, Erpelinck-Verschueren CA, van Putten WL, Valk PJ, Delwel $R$ (2009) Double CEBPA mutations, but not single CEBPA mutations, define a subgroup of acute myeloid leukemia with a distinctive gene expression profile that is uniquely associated with a favorable outcome. Blood 113: 3088-3091. doi:10.1182/blood-2008-09179895

Ye M, Zhang H, Amabile G, Yang H, Staber PB, Zhang P, Levantini E, AlberichJorda M, Zhang J, Kawasaki A, et al (2013) C/EBPa controls acquisition and maintenance of adult haematopoietic stem cell quiescence. Nat Cell Biol 15: 385-394. doi:10.1038/ncb2698

Yue F, Cheng Y, Breschi A, Vierstra J, Wu W, Ryba T, Sandstrom R, Ma Z, Davis C, Pope BD, et al (2014) A comparative encyclopedia of DNA elements in the mouse genome. Nature 515: 355-364. doi:10.1038/nature13992

Zhang P, Iwasaki-Arai J, Iwasaki H, Fenyus ML, Dayaram T, Owens BM, Shigematsu H, Levantini E, Huettner CS, Lekstrom-Himes JA, et al (2004) Enhancement of hematopoietic stem cell repopulating capacity and self-renewal in the absence of the transcription factor C/EBP alpha. Immunity 21: 853-863. doi:10.1016/j.immuni.2004.11.006

Zhao L, Glazov EA, Pattabiraman DR, Al-Owaidi F, Zhang P, Brown MA, Leo PJ, Gonda TJ (2011) Integrated genome-wide chromatin occupancy and expression analyses identify key myeloid pro-differentiation transcription factors repressed by Myb. Nucleic Acids Res 39: 4664-4679. doi:10.1093/nar/gkr024

Zhao L, Ye P, Gonda TJ (2014) The MYB proto-oncogene suppresses monocytic differentiation of acute myeloid leukemia cells via transcriptional activation of its target gene GFI1. Oncogene 33: 4442-4449. doi:10.1038/onc.2013.419

Zuber J, Rappaport AR, Luo W, Wang E, Chen C, Vaseva AV, Shi J, Weissmueller S, Fellmann C, Taylor MJ, et al (2011) An integrated approach to dissecting oncogene addiction implicates a Myb-coordinated selfrenewal program as essential for leukemia maintenance. Genes Dev 25: 1628-1640. doi:10.1101/gad.17269211

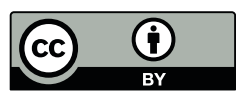

License: This article is available under a Creative Commons License (Attribution 4.0 International, as described at https://creativecommons.org/ licenses/by/4.0/). 